\title{
EFFECTS OF FTORAFUR AND 5-FLUOROURACIL ON THE CANINE SINOATRIAL NODE
}

\author{
Hiroyasu SATOH and Keitaro HASHIMOTO \\ Department of Pharmacology, Yamanashi Medical College. Tamaho. \\ Nakakomagun, Yamanashi 409-38, Japan
}

Accepted November 10, 1982

\begin{abstract}
Effects of ftorafur and 5-fluorouracil (5-FU) on the canine sinoatrial node were studied using isolated sinoatrial node and an atrial preparation which were obtained from puppies and perfused with oxygenated Tyrode solution through the dorsal right atrial artery (sinus node artery). The injection of ftorafur and 5-FU caused positive inotropic and chronotropic effects. However, the solvent of 5 -FU caused similar effects. These positive inotropic and chronotropic effects were not abolished by pindolol. Verapamil did not alter the effects of ftorafur and 5-FU. Also a change in extracellular calcium concentration and aminophylline did not affect the positive chronotropic and inotropic responses to the two agents. These findings suggest that ftorafur may induce the positive responses by direct action.
\end{abstract}

Ftorafur and 5-FU are widely used as anticancer agents and are known to induce gastrointestinal side effects, myelosuppression, dermatologic changes, and neurotoric effects. Recently, it was reported (1-5) that ftorafur and 5-FU also had cardiotoxicity. Roth et al. (1) reported that a patient complained of mild precordial pain and his electrocardiogram indicated ischemic changes in the anterior wall, when the patient had received a total of $4.500 \mathrm{mg}$ of 5 -FU. Mechanisms proposed for 5-FU-induced cardiotoxicity were a direct toxic effect on myocardial cells and an autoimmune reaction (3). We wanted to clarify cardiac actions of ftorafur and 5-FU and their mechanisms by studying the effects of these agents on the automaticity of canine sinoatrial node cells and contraction of atrial muscle.

\section{Materials and Methods}

Fifteen mongrel puppies of either sex. weighing 2 to $5 \mathrm{~kg}$ (approximately 3 to 5 months old), were used. The details of the isolated sinoatrial node and atrial preparation were reported in previous papers $(6,7)$. In brief, after an i.v. injection of sodium pentobarbital ( $30 \mathrm{mg} / \mathrm{kg}$ ), the chest was opened and the heart was removed. The right coronary artery was dissected at near the branch of the sinus node artery and cannulated with a non-slip catherter. The preparation was maintained at $36 \pm 1^{\circ} \mathrm{C}$ in an organ bath and perfused with Tyrode solution through the sinus node artery at a constant flow rate of $3 \mathrm{ml} / \mathrm{min}$. The composition of the Tyrode solution was (in $\mathrm{mM}$ ): $\mathrm{NaCl}, 137 ; \mathrm{KCl}, 4.0$; $\mathrm{CaCl}_{2}, 1.9 ; \mathrm{NaH}_{2} \mathrm{PO}_{4}, 0.4: \mathrm{NaHCO}_{3}, 11.9$; and glucose, 5.5; and it was bubbled with $95 \% \mathrm{O}_{2}$ and $5 \% \mathrm{CO}_{2}$. The $\mathrm{pH}$ of the solution was 7.4. The drugs were injected using a microsyringe (Terumo N-100) through a rubber tube which was connected to the sinus node artery. Five $\mathrm{ml}$ of the ftorafur injection (Taiho Pharmaceutical Co.) contained $400 \mathrm{mg}$ ftorafur, $180.4 \mathrm{mg} \mathrm{NaHCO}$ and $40 \mathrm{mg} \mathrm{NaOH}$; this had a $\mathrm{pH}$ of 9.5-10.5. Five $\mathrm{ml}$ of $5-\mathrm{FU}$ injection (Kyowa Hakko 
Kogyo Co.) contained $250 \mathrm{mg} 5-\mathrm{FU}$ and $423.5 \mathrm{mg}$ Tris-hydroxymethyl aminomethane: this had a $\mathrm{pH}$ of 8.5. The action potential of the sinoatrial node cells was recorded by penetrating a glass microelectrode from the epicardial side. The atrial contraction was measured using a Nihon Kohden forcedisplacement transducer.

Other drugs used in this study were pindolol (Sandoz A.G.), noradrenaline (Nakarai Chemical Co.), verapamil (Eisai Co.) and aminophylline (Sigma Chemical $\mathrm{Co}$.).

\section{Results}

\section{Effects of ftorafur and 5-FU injections on} the sinoatrial node: $5-\mathrm{FU}$ and ftorafur, 500 to $1500 \mu \mathrm{g}$, induced dose-dependent positive inotropic and chronotropic effects (Figs. 1 and 2, $n=16$ ). There were little difference between ftorafur- and 5-FU-induced effects. However, the solvent of 5-FU alone produced positive effects similar to those produced by 5-FU injection. The solvent of ftorafur had weaker positive chronotropic and inotropic effects (Fig. 3, n=8).

Changes in the action potential configurations of the sinus nodal area during the positive chronotropic responses to these drugs are shown in Fig. $4 \quad(n=10)$. There were no statistically significant changes in the amplitude and the duration of the action potential ( $90 \%$ of repolarization). The positive chronotropic effects of ftorafur and 5 -FU were due to increases in the rate of phase 4
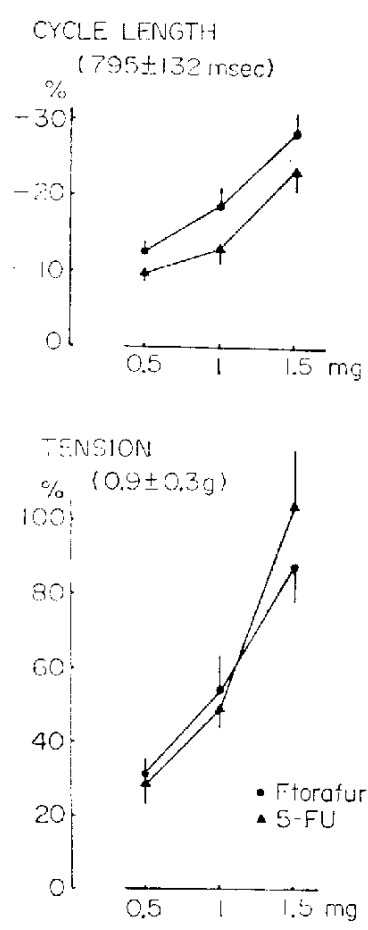

Fig. 2. Dose-response relationships of 5-FU and ftorafur on cycle length and atrial tension. Numbers in parenthesis represent the initial values. Vertical bars represent the S.E.M.

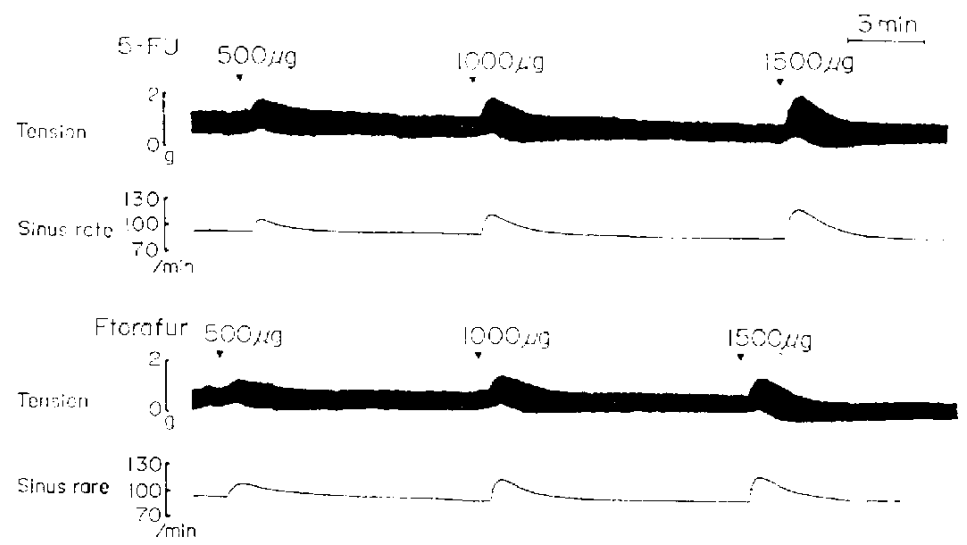

Fig. 1. Positive inotropic and chronotropic effects of 5-FU and ftorafur injections on the canine sinoatrial node. 
depolarization.

Effect of pindolol on the positive responses to ftorafur and 5-FU: The effect of pindolol on the positive chronotropic and inotropic responses to ftorafur and 5-FU was studied in 6 dogs. Typical results are shown in Fig. 5. An injection of $1.2 \mathrm{\mu g}$ of pindolol had no direct effect, but blocked the effect of $0.1 \mathrm{~kg}$ of noradrenaline. whereas the responses to ftorafur and 5-FU were unchanged.

Effect of verapamil on the positive responses to ftorafur and $5-\mathrm{FU}$ : In 5 preparations, $2.5 \mu \mathrm{g}$ of verapamil, a Ca-channel inhibitor. was used, and it depressed the tension and sinus rate. The positive responses to ftorafur and 5-FU were not altered after treatment with verapamil (Fig. 6). Verapamil

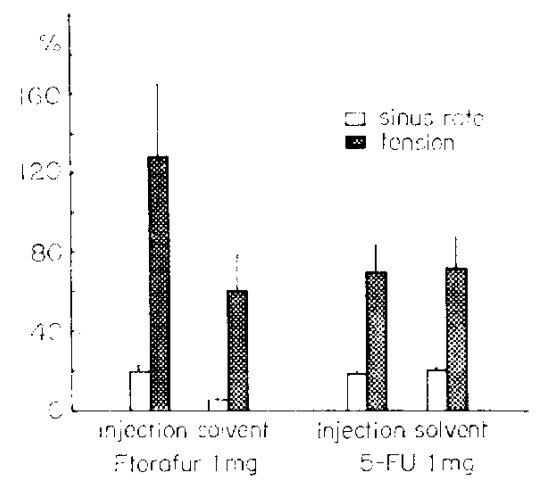

Fig. 3. Comparison of the effects of ftorafur and 5-FU injections and the solvents. There were no differences in the effects of 5-FU injection and its solvent on both cycle length and tension. Vertical bars represent the S.E.M. suppressed only the positive chronotropic effects induced by $1 \mathrm{mg}$ of $\mathrm{CaCl}_{2}$, but did not affect the positive inotropic effect by it. The results suggest that the inhibitory action of verapamil has become weaker by application of $1 \mathrm{mg}$ of $\mathrm{CaCl}_{2}$ since verapamil inhibits the inward calcium current in a competitive manner for $\mathrm{Ca}^{2+}$ on the membrane site. The difference, which verapamil suppressed the positive chronotropic response by $\mathrm{CaCl}_{2}$ but not the positive inotropic response induced by it, would result
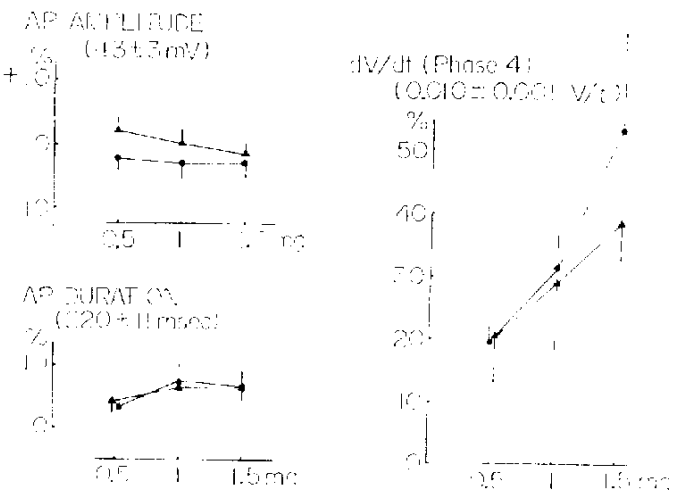

Fig. 4. Dose-response relationships of 5-FU and ftorafur injections on action potential parameters. On the ordinate, the percentage of changes in parameters are presented. Amplitude of action potential (upper, left) and duration of action potential $(90 \%$ repolarization) (lower. left) were little affected. The slope of phase 4 depolarization (dV/dt (phase 4)) (right) was significantly increased. Numbers in parenthesis represent initial values. Solid circles indicate ftorafur, and solid triangles indicate 5-FU. Vertical bars represent the S.E.M.

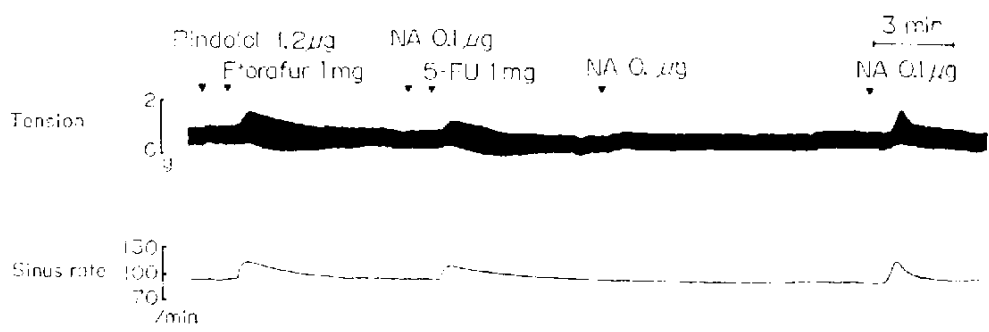

Fig. 5. Effect of pindolot on the positive responses to ftorafur and 5 - FU. In the presence of $1.2 \mu \mathrm{g}$ of pindolol, ftorafur and 5-FU produced positive responses, but the effect of $0.1 \mu \mathrm{g}$ of noradrenaline (NA) was blocked completely, and was recovered after about $20 \mathrm{~min}$. 
because inotropism might have a more sensitive dependence upon $\mathrm{Ca}^{2 .+}$ ions than chronotropism.

Effect of low $\mathrm{Ca}^{2+}$ concentration on the positive responses to ftorafur and $5-\mathrm{FU}$ : When the extracellular $\mathrm{Ca}^{2+}$ in Tyrode solution was decreased from 1.9 to $1.0 \mathrm{mM}$, both the tension and sinus rate were decreased. Low
Ca did not affect the positive inotropic and chronotropic effects of ftorafur and 5-FU and also those of $1 \mathrm{mg}$ of $\mathrm{CaCl}_{2}$ (Fig. 7. $n=5$ ).

Effect of aminophylline on the positive responses to ftorafur and 5-FU: Aminophylline, an inhibitor of phosphodiesterase, increased the contraction of atrial muscle and the sinus rate. In the presence of $250 \mu \mathrm{g}$

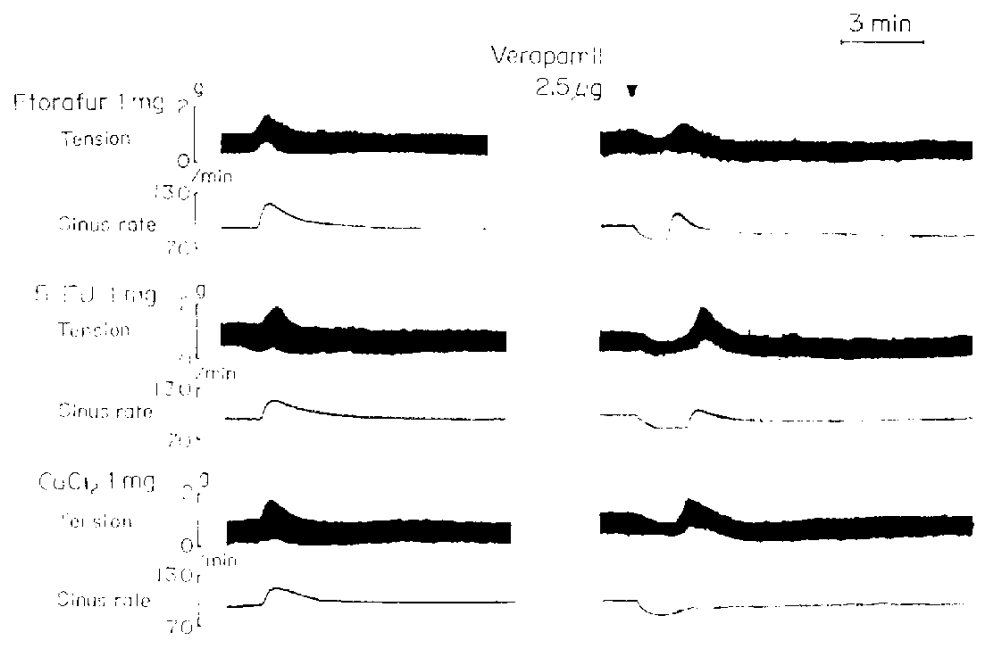

Fig. 6. Effect of verapamil on the positive responses to 5 -FU and ftorafur. Administration of $2.5 \mu \mathrm{g}$ of verapamil caused direct depressions in tension and sinus rate. The offects of ftorafur and 5-FU were not affected, but the positive chronotropic effect of $\mathrm{CaCl}_{2}$ was suppressed. Effect of $\mathrm{CaCl}_{2}$ on the contraction was unchanged.

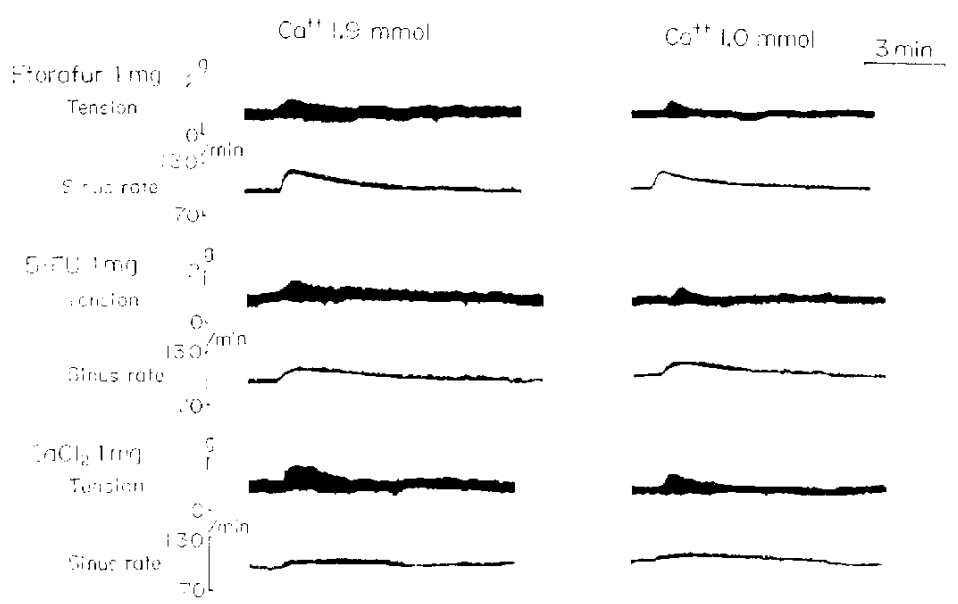

Fig. 7. Effect of low Ca concentration on the positive responses to 5-FU and ftorafur. During depression after extracollular Ca dropped from 1.9 to $1.0 \mathrm{mM}$, there was no changes in atrial contraction and the sinus rate. 


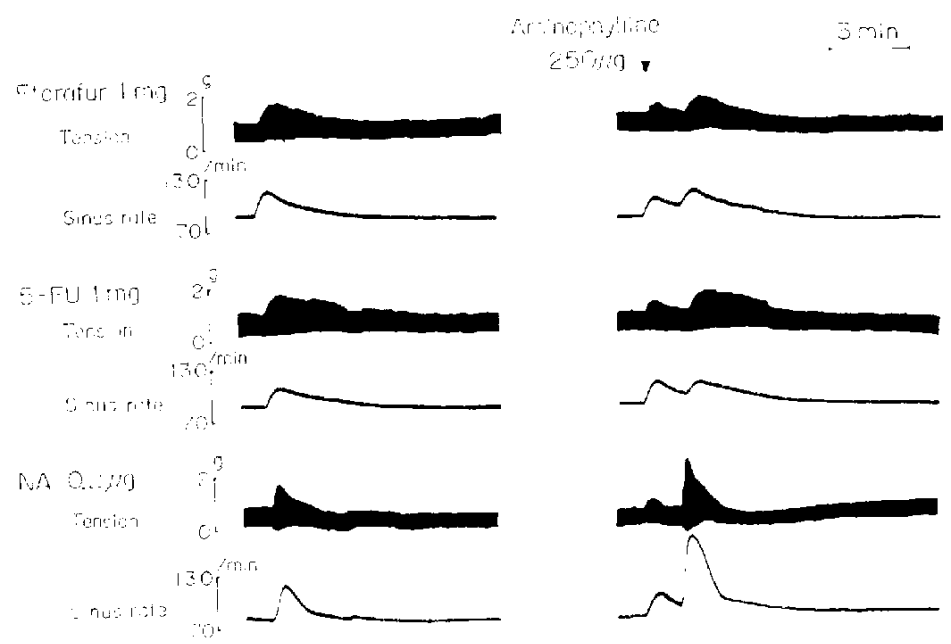

Fig. 8. Effect of aminophylline on the positive responses to 5-FU and florafur. In the presence of $250 \mu \mathrm{g}$ of aminuphylline, positive responses to $0.2 \mu \mathrm{g}$ of noradrenaline (NA) was potentiated, but effects of ftorafur and $5-\Gamma U$ woro unchangod.

aminophylline, the effects of ftorafur and 5 FU were not altered, while those of 0.2 ing of noradrenaline was markedly potentiated (Fig. $8, n=6$ ).

\section{Discussion}

We examined the effects of anticancer agents, ftorafur and 5-FU, on the canine sinoatrial node. Both agents produced positive inotropic and chronotropic responses. How ever, both drugs need alkaline solvent, and only for ftorafur, there was a significant difference between the effects of the drug and the solvent on the chronotropic and inotropic effects $(P<0.05)$. All the cardiac effects of $5-\mathrm{FU}$ seem to be due to the solvent. The positive chronotropic actions of ftorafur and 5 -FU were brought about by the increase in rate of phase 4 depolarization. The mechanisms of the positive chronotropic and inotropic responses were examined under several conditions. The positive responses were not affected by pindolol and aminophylline. Verapamil and lower extracellular Ca concentration did not affect the positive responses induced by ftorafur and 5-FU. These results indicate that the positive inotropic and chronotropic responses to ftorafur and 5-FU were not mediated by a beta-receptor, and they were not related to increased cyclic AMP. Furthermore, it seems that the positive responses were not directly related to the Ca current across the cell membrane. From these results, it is difficult to explain the actions of these drugs, but we would like to speculate about changes in the sensitivity of myofilaments to $\mathrm{Ca}$ and/or the uptake and release of $\mathrm{Ca}$ by the sarcoplasmic reticulum. These responses to both injections might also involve other yet unknown mechanisms. Part of the effects may be produced by high $\mathrm{pH}$. Indeed high $\mathrm{pH}$ has positive chronotropic and inotropic effects (8). We could not demonstrate any cardiac effects of ftorafur and 5-FU which may be related to cardiotoxicity. It is possible that there may be a species difference in the sensitivity to ftorafur and 5-FU in man and dog. In other species, Suzuki et al. (9) found that myocardial mitochondria taken from 5 FU-treated rabbits showed a low respiratory control ratio. Matsubara et al. (10) using the guinea pig indicated that the cardiotoxicity was due to a depletion of the high-energy 
phosphate compounds of the ventricular myocardium, suggesting a malfunction of the TCA cycle resulting from an inhibition of aconitase by fluorocitrate.

\section{References}

1) Roth, A., Kolaric, K. and Popovic, S.: Cardiotoxicity of 5-fluorouracil (NSC-19893). Cancer Chemother. Rep. 59, 1051-1052 (1975)

2) Dent, R.G. and McColl, I.: 5-Fluorouracil and angina. Lancet $1,347-348(7975)$

3) Lang Stevenson, D., Mikhailidis, D.P. and Gillett, D.S.: Cardiotoxicity of 5-fluorouracil. Lancet 2, 406-407 (1977)

4) Pottage, A., Holt, S., Ludgate, S. and Langlands, A.O.: Fluorouracil cardiotoxicity. Br. Med. J. 1,547 (1978)

5) Soukop, M., McVie, J.G. and Galman, K.C.: Fluorouracil cardiotoxicity. Br. Med. J. 1, 1422
(1978)

6) Woods, W.T., Katholi, R.E., Urthaler, F. and James, T.N.: Electrophysiological effects of magnesium on cells on the canine sinus node and false tendon. Circ. Res, 44, 182-188 (1979)

7) Satoh, H., Nakajima, T., Hashimoto, K. and Imai, S.: Effects of lidocaine and procaine on the action potential of the canine sinus node cells. Japan. Heart J. 22, 929-937 (1981)

8) Satoh, H. and Hashimoto, K.: Effect of pH on the sino-atrial node cells and atrial muscle of dog. Arch. Int. Pharmacodyn. Ther. (in press)

9) Suzuki, T., Nakanishi, H., Hayashi, A., Nakahata, N., Takano, S. and Ito, G.: Cardiac toxicity of 5 -fluorouracil in rabbits. Japan. J. Pharmacol. 27. Supp. 137P (1977)

10) Matsubara, I., Kamiya, J. and Imai, S.: Cardiotoxicic effocts of 5 -fluorouracil in the guinea pig. Japan. J. Pharmacol. 30, 871-879 (1980) 